\title{
1. Take-off, expansion and implosion
}

This chapter presents a historical account of the overseas Chinese democracy movement in order to lay a contextual foundation for the investigation of the more current developments in subsequent chapters. First, it analyses the genesis and dynamic growth of the movement after CAD was founded. Second, it examines CAD activists' roles in the 1989 Tiananmen Square demonstrations. Third, the chapter looks at the booming growth of the movement since 1989. Fourth, it sheds light on incessant intra-movement infighting as a key factor that threatened to cripple the movement from the mid-1990s, causing the decline of its overall momentum from the turn of the century.

\section{SPROUTING OF AN EXILE MOVEMENT}

In 1979, the PRC sent its first group of students to the West. Among them was Wang Bingzhang. Before he arrived at McGill University to pursue a medical $\mathrm{PhD}$ in October that year, Wang spent months attending study-abroad training programmes in Beijing, witnessed the robust development of the Democracy Wall movement, and felt depressed following the arrest of the leading activists such as Wei Jingsheng. Already disillusioned with the political regime thanks to his experience as a Red Guard leader during the Cultural Revolution, Wang's study abroad corresponded with the arrest, trial and sentencing of more Democracy Wall activists and liberal intellectuals. ${ }^{1}$ As a result, collaborating with some fellow students and scholars who shared his transformative experience in China and concern about ongoing persecution, Wang abandoned his promising medical career and decided to publish a dissenting China Spring (CS) monthly magazine in order to carry the torch of the Wall.

\footnotetext{
1 Wang, Bingzhang (1982), 'Declaration to leave medical career for democracy movement: for the motherland's spring', Zhongguo Zhichun (China Spring, hereafter CS), December, pp. 30-32. For a profile of Wang Bingzhang as a legendary activist, see Cao, Yaxue (2013), 'In the prison of China - the journey of Dr. Wang Bingzhang (parts 1, 2 and 3)', China Change, available at https://chinachange.org/2013/10/01/in-the-prison-of-chinathe-journey-of-dr-wang-bingzhang-1/.
} 
When the inaugural issue was published in New York in December 1982, it caught the wide attention of major US newspapers and ethnic Chinese media. Many local ethnic Chinese academics, community leaders and owners of media outlets offered enormous support for the magazine and this handful of daring mainland Chinese students, by staging public relations events, building connections to the mainstream media, printing and marketing of the magazine, and collecting donations. Consequently, the magazine sold spectacularly well and received enthusiastic feedback from Chinese communities and students in the US, Japan, Europe, Taiwan, Hong Kong, and even mainland China. Wang and his fellow travellers toured the US to give speeches to propagate their democratic ideas. The contagious effect of the CS magazine and its operators worldwide culminated in the founding of the CAD in New York in December 1983. Fifty-three delegates travelled from the Americas, Europe, Australia, Japan, Hong Kong, Taiwan and China to announce the birth of the first political opposition organization by those of mainland Chinese background. ${ }^{2}$

Since its inception, CAD developed its core membership from Chinese students in an increasing number of university campuses in the US, Japan, Europe and Australia. More unreserved support came from a large number of Chinatowns-based anti-communist cold warriors, namely those overseas Chinese elite whose anti-Beijing sentiment resulted from their own or their parents' direct suffering at the hands of Chinese communists at the end of the Civil War in 1949. Throughout the 1980s, these leaders of the community of Laoqiao (old generation Chinese migrants) dominated the politics of Chinatowns in the US and other Western nations. Their ideological battle, through associations and newspapers, was often sustained by the authoritarian regime of the ruling Kuomintang (KMT, or the Chinese Nationalist Party) in Taipei, as part of an all-out overseas civil war against Beijing. As Ding Chu, the then CAD Secretary General recalled, when the organization started to take off, these pro-KMT elements absolutely controlled political life in the roughly half a million-strong Chinese community in New York. Each year lavish celebrations and parades were staged for the ROC's Double Ten (10 October) national day in each major US city, yet the PRC's 1 October national day failed to see any organized mass celebration. While these Laoqiao cold warriors initially distrusted the mainland Chinese arrivals as CCP sympathizers, they quickly saw the CAD activists as

2 Chen, Li and Lu Wei (1993-4), 'A ten-year history of the Chinese Alliance of Democracy (serial)', CS and Beijing Zhichun (Beijing Spring, hereafter BS), available at http://beijingspring.com/wj3/List.asp?boardID=1. 
fellow anti-communist crusaders. ${ }^{3}$ Some pro-KMT migrants from Taiwan (mostly mainlanders) also became leading activists in the budding CAD.

The party-state establishment in Taipei headed by President Chiang Ching-kuo was openly behind this developing campaign against its sworn enemy in Beijing. In those years, officials of the Overseas Chinese Cultural and Educational Service Centres (representing the Overseas Community Affairs Commission), the KMT's own Overseas Working Committee, and the party's extensive branches abroad, all worked on the Chinese diaspora. ${ }^{4}$ From Taipei's point of view, CAD was a godsend in that it was the first proper dissident organization initiated voluntarily by the fresh mainland Chinese people in the "free world". In its quintessential ideological jargon, Wang Bingzhang and his comrades were seen as "defecting to freedom". In fact, in 1979, when the Democracy Wall movement was still sweeping throughout China, Taipei's agents infiltrated China and tried to hand cash to some activists in the provinces in order to fuel political dissent. Shortly before the founding of CAD, Taipei's Military Intelligence Bureau (MIB, of the Ministry of National Defence) urged Xue Wei, a much publicized political refugee from Sichuan province, to organize a government in exile in New York. ${ }^{5}$ Indeed Taipei was so engrossed in functioning as an anti-CCP fortress that it took the trouble to repatriate to the island six criminal hijackers who forced a domestic mainland passenger plane en route from Shenyang to Shanghai to land in Seoul in May 1983, seven months before CAD's founding. Though all six were convicted of their hideous crime by a court in South Korea, once "rescued" to Taipei they were treated as honourable anti-communist warriors, showered with titles and cash, and enjoyed President Chiang's personal reception. ${ }^{6}$

Funding flooded from the ROC to the CAD cohort. According to Xue, who eventually collaborated with Wang to form the organization, the bulk of the money was channelled through the MIB. The CAD received about US\$60 000 each month, half for organizational maintenance and half for

3 Ding, Chu (2009), Dameng shui xian jue: Zhongguo Zhi Chun yu wo de minyun lichen [Awakening from a Mighty Dream: China Spring and my Democracy Movement Road], Hong Kong: Haifeng Publishing Co., pp. 137-8.

4 Ya, Yi (2005b), 'Scholars' anxiety and mission - interview with Dr. Yun Zhongjun, Director of Overseas Chinese Cultural and Educational Service Centre in New York', in Liuwangzhe fantan lu [Interviews with Exiles], Hong Kong: Sheffield Press, pp. 587-97.

5 Interview with Xue Wei, president of CAD (2004-15), general manager of $B S$, New York, 20 December 2014.

6 Xu, Bingchuan (2001), 'Mainland plane hijacker Zhuo Changren has been executed in Taiwan', Remin Wang (People Net), 15 August, available at http://www.people.com.cn/ GB/shehui/44/20010815/535721.html. South Korea maintained diplomatic relations with ROC at the time, until 1991. 
the running of its magazine CS. The Taiwanese money made it easy to stage CAD's proliferating activities, including the grand annual world congress attended by delegates from many branches all over the world. ${ }^{7}$ Ding Chu's memory of 1987 suggests that a total of 14 activists in the headquarters and branches in Japan, Hong Kong and France were paid monthly. Wang Bingzhang was paid US $\$ 1000$ per month, and the rest US $\$ 800$ per month each. ${ }^{8}$ The mainland dissidents were cognizant of the authoritarian nature of the KMT regime. The first issue of $C S$ in December 1982 ran a public letter penned by Wang and his colleagues which criticized both the mainland and Taiwan governments for their one-party dictatorships, as if the budding political movement in North America was a pure third force to bring fresh ideas to the nation's democratization and unification. ${ }^{9}$ The original constitution of the CAD adopted in December 1983 proclaimed that the alliance followed the principle of independence and autonomy between the CCP and KMT on the causes of China's democratization and unification. Despite such rhetoric, Taipei's generosity gradually turned CAD into a pro-KMT group. Until 1989, Wang was requested to abandon his ideas of establishing a CAD presence and distributing $C S$ in Taiwan. ${ }^{10}$ However, CAD had not become a tool of the KMT regime. Close comrades of Wang at the time (now serving life sentences in jail in China) recall that Wang and other activists were frustrated with Taipei's interference but still tried their utmost to make the best use of its money for their own cause while manoeuvring to stay independent (more about autonomy in dependency in Chapter 2). ${ }^{11}$

CAD activists learned about and capitalized on the free environment in host states to experiment with various campaigns with a sense of excitement. It was all about pro-democracy activism on trial. One instinctive activity was to assist and incite Chinese visitors in the US to seek political asylum. The purpose was not just to help those who needed protection but also inform the US authorities and society of the situation of political persecution in China. The CAD activists helped more than 300 asylum seekers to successfully receive protection by providing legal advice, translation services and testimony in court. Taking the lead responsibility in this program was Xue Wei. Before coming to study in

Interview with Xue Wei.

Ding (2009), pp. 44, 55.

9 China Spring Editorial Office (1982), 'A letter to domestic and overseas compatri-

ots', CS, December, pp. 5-6.

10 Interview with Xue Wei.

11 Ibid. 
the US in 1980, he spent ten years in jail charged with the crime of "counter-revolution". Despite this background and his role as the publisher of $C S$ and a founding member of CAD, Xue's asylum application was initially rejected by the immigration authorities. He eventually won the case through court proceedings by leveraging the Convention Relating to the Status of Refugees in early 1984. This created an unprecedented case of a mainland Chinese person obtaining refugee status by challenging the US authorities in court. He and others set up a "defect to freedom" hotline, and tried to incite defection of the Chinese athletes competing in the 1984 Los Angeles Olympic Games by sneaking into restaurants where the athletes were celebrating, and placing how-todefect brochures and CS materials underneath the diners' plates. ${ }^{12}$

Against the background of student demonstrations in China (December 1986-January 1987) demanding greater economic and political freedoms, the CAD mobilized student representatives from many universities in the US to write a public letter in support of the demonstrations back home, expressing opposition to the authorities' crackdown on fellow students and intellectuals. Their lobbying on Capitol Hill ensured that the US Senate held a public hearing on human rights issues in China and passed a resolution urging the administration to treat any asylum application from Chinese students sympathetically. ${ }^{13}$ On record, this was the first Congressional campaign by a Chinese dissident group.

The most meaningful experiment of democracy was to challenge the legitimacy of the Chinese Students and Scholars Association (CSSA), the officially controlled organization for overseas Chinese students and scholars registered in most universities in the West. The spark was ignited by the two leaders of CAD's Kentucky Branch studying at the University of Kentucky in Lexington. In an election of the leadership of the university's CSSA in May 1988, Wu Fangcheng and Ren Songlin, who openly identified themselves as CAD members, defeated the candidates endorsed by the Chinese embassy and became elected as the president and deputy president. Embassy officials rushed to the scene several times to try to nip in the bud the first independent Chinese student body in the US, only to be fiercely debated by Wu. Despite threat and intimidation from the embassy, and anxiety felt by the student community, the new leadership started to function and their work was supported by the members. As a result, the embassy refused to recognize the validity of the election results, and set up a separate official body. Symbolically, this

12 Chen, Li and Lu Wei (1993-4); Interview with Xue Wei.

13 Chen, Li and Lu Wei (1993-4). 
was CAD's first face-to-face combat against the CCP, and a peaceful competition too. Wu later recalled that the co-existence of two rival student organizations in the same campus guaranteed healthy competition in enriching students' lives and providing benefits. ${ }^{14}$ With sufficient democracy exercises overseas like this, imaginations began to indulge the possibility that one day a CAD-turned-opposition might effectively engage the CCP in free elections in China. Considering the enlightening implications of the Kentucky model, the CAD machinery was mobilized in full gear to support $\mathrm{Wu}$ and Ren in their campaigns and collected donations to support their free association. ${ }^{15}$

Membership of CAD expanded rapidly. By January 1989, there were more than 600 fee-paying members in the official registrar, with 85 in the New York branch, the largest one in the world. ${ }^{16}$ Altogether the CAD had established 21 branch offices in Asia, Europe and North America. A domestic network in China had also been developed with branches in Guangzhou, Shanghai, Beijing, Nanjing, Changsha, Chongqing, Shenyang, Shandong, Jianxi, Hebei, Guizhou, and Yunnan. ${ }^{17}$

The CCP had clearly felt the impact. When CS first emerged, paramount leader Deng Xiaoping addressed a Central Work Conference and explicitly singled out Wang Bingzhang and the magazine as advocates of wholesale capitalism. Deng went on to denounce $C S$ on many occasions. In particular, at the Sixth Plenary Session of the tenth CCP Central Committee in September 1986, Deng made a speech warning the party against the so-called bourgeois liberalization, in which he referred to Wang Bingzhang as among "those representative of this ideological trend". ${ }^{18}$ This concern was grounded on the wide underground circulation of copies of $C S$ brought secretly into China. Politically active students in 1986-7 were heartened by $C S$ ' coverage of overseas support for their campaigns. Some still vividly remember reading a report on the CAD's 1985 defamation suit against The People's Daily in DC Superior Court, which the CCP mouthpiece dodged by using some sort of diplomatic

14 Ya, Yi (2005a), 'Democracy can save the country - interview with CAD president Wu Fangcheng', in Liuwangzhe fantan lu [Interviews with Exiles], pp. 466-75; Ren, Songlin (2013), 'Memory of Kentucky - in honour of brother Wu Fangcheng', Zonglan Zhongguo (China in Perspective), available at http://www.chinainperspective.com/ ArtShow.aspx?AID=20900; Shu, Ge (1988), 'Kentucky: who is creating split among the students?', CS, December, pp. 60-61.

15 Ding (2009), pp. 165-6.

16 Ibid., p. 204.

17 Zhang (1990), pp. 12-13.

18 Chen, Li and Lu Wei (1993-4). 
immunity. ${ }^{19}$ From late 1987 to early 1988, the Chinese authorities used television and radio broadcasting and print media to demonize the CAD and CS. A policy document was circulated to numerous work units throughout the country which classified them as "reactionary". Authorities at various levels were told to instruct people not to contact the CAD or read CS. Anyone who received CAD print materials must turn them over to the authorities. Meanwhile, special agencies were created to flush out CAD cells. ${ }^{20}$

\section{CAD AND THE TIANANMEN DEMOCRACY MOVEMENT}

What thwarted a further upsurge of the CAD's momentum was not the Chinese government, but the organization's own internal feuding. Worst of all, it flared up just before the Tiananmen Square democracy movement in Beijing. The activists who were based in Flushing, the main Chinatown district in New York, and CAD headquarters and the CS office, failed to anticipate this historic event. In January 1989, Wang Bingzhang's colleagues, including the new CAD President $\mathrm{Hu}$ Ping elected in 1987, accused Wang of undemocratic behaviour, consisting of continuing to interfere in the leadership, personal profiteering from assisting asylum seekers, and black-box operations in financial affairs. What unfolded in the following months seemed little less than a promising political opposition in exile trying to derail itself. The new leadership issued an announcement to expel Wang from the central executive council. This split the organization, with the CAD branches in Nebraska, Chicago, Hong Kong and Australia opposing the decision, while those in Kentucky, Washington, Los Angeles and Japan supported it. Meanwhile, Wang seized the funds of the organization, which he alone had controlled, causing severe financial difficulties for CS. In March the central council voted to strip Wang of his CAD membership altogether. Just under 100 members left the organization to join Wang in an attempt to form a rival Democracy Party. This nearly caused a mortal wound to CAD, culminating in the total collapse of its branches and liaison offices in Chicago, Paris, Nebraska, Seattle, Utah and Canada, and the emergence of two rival factions in the New York branch. ${ }^{21}$

19 Ibid.

20 Ibid.

21 Ibid.; Interview with Xue Wei; Ding (2009), pp. 214-33. 
The infighting damaged the image of CAD, since the cause of the saga was widely perceived in the Chinese community as a power struggle. In hindsight, it was also a harbinger for what was to become normal; that is, despite their heroic personal history, well-respected and highly educated democracy fighters might not be able to collaborate with each other to mount a coordinated struggle. Instead, they only obstructed one another's contributions to the cause, particularly if they found themselves in the same organization. Hu Ping, a postgraduate at the Beijing University during the Democracy Wall movement, was already a legendary liberal intellectual before coming to Harvard to study for a $\mathrm{PhD}$ in 1987. His 1979 essay "On Freedom of Speech" has been widely read and is remembered as one of the most important theoretical accomplishments of that movement. However, serious soul-searching over infighting and its consequences failed to materialize thanks to the excitement aroused by the gathering of protestors in Tiananmen Square after mid-April 1989. $\mathrm{CAD}$ responded to the developing protests while trying to recuperate from the self-damaging infighting. Many student activists in the square, such as Wuer Kaixi, a leader of self-governing Beijing Students' Autonomous Federation (BSAF) formed in the middle of the protest, had in fact been aware of $C S$, and always felt excited and inspired by the existence of this overseas movement. ${ }^{22}$ In that sense, it was lamentable that CAD, supposedly China's only political opposition organization at the time, had just weakened its potential as a leading overseas support force when an epic democracy campaign was in full swing in China itself. Still, the CAD activists in the headquarters and branches managed to mobilize and provide substantial assistance to the campaigns of students and intellectuals both at home and abroad.

It must be stressed that one should not infer or exaggerate CAD's significance from Beijing's own standard propaganda at the time attributing the Tiananmen protests to the direct instigation of CAD and other overseas "anti-China forces". At a press conference on 3 May 1989, Yuan $\mathrm{Mu}$, the spokesman of the State Council, claimed that students' strikes and protests in Beijing were all plotted by an extreme few, such as some members of the "reactionary" CAD. ${ }^{23}$ Such blanket claims were often made when the government referred to isolated actions of some individual CAD members visiting China. For example, Chen Jun returned to

\footnotetext{
22 Chen, Li and Lu Wei (1993-94).

23 New China News Agency (1989), 'Yuan Mu addresses the Chinese and foreign correspondents on issues including the petition letter and dialogue', Tiananmen Duizhi (Standoff at Tiananmen), 3 May, available at http://www.tiananmenduizhi.com/2015/05/ blog-post.html.
} 
China after finishing his study in the US in 1987 and opened a bar in Beijing to provide a place of association for liberal intellectuals. Early in 1989 Chen initiated an open letter to the Chinese government, which was later co-signed by 32 other renowned intellectuals, calling for respect of human rights and release of all political prisoners. Yang Wei, another member of CAD returning from the US, led a Shanghai student organization during May-June to respond to their comrades in Beijing. ${ }^{24}$ The authorities fully capitalized on these personal acts to implicate their organization and belittle the legitimacy of the student movement as a whole. On the other hand, Taipei's boasting of CAD's crucial role in Tiananmen should also be taken with a pinch of salt, since it smacked of an attempt to take the credit for itself. Although it is impossible to present an accurate analysis of CAD's role in 1989, sufficient evidence exists to depict it as the leading overseas political organization in support of the protests, predominantly in action from afar.

Protests in Beijing triggered an aspiration for independent organizations in the student communities overseas. The saga of free elections at the University of Kentucky in Lexington in 1988 had been celebrated by CAD as "the first shot from Lexington" in the Chinese students' quest for independent representation, likened to the legendary first shot from Lexington of Massachusetts in the American War of Independence. This first shot was echoed en masse in April-June 1989, leading to a dissenting students' takeover of all CSSAs in universities in Western countries through democratic procedures and with mass support. The CSSA at the University of Kentucky led by Wu Fangcheng and Ren Songlin, hitherto the only independent Chinese student organization in the US, organized fellow students to hold mass rallies and enjoyed popular support from students in that university to lodge petitions inside the Chinese Consulate General in Chicago. Meanwhile, the two CAD activists advised other campuses how to organize independent student unions and initiated the formation of an Independent Federation of Chinese Students and Scholars (IFCSS) in the Mid-Western US, which culminated in the establishment of the All-US IFCSS. Poignantly, as if to demonstrate the ultimate victory from the "first shot from Lexington", leaders of the Chinese embassy-controlled CSSA at the University of Kentucky, moved to tears by the Beijing massacre, announced that they would dissolve the already collapsing organization on 5 June 1989.25

24 Zhang (1990), p. 15; Bi, Shujun (1991), 'Experience of my son Yang Wei being arrested twice', CS, February, pp. 12-16.

25 Ren (2013). 
As for the CAD headquarters, it organized mass rallies in New York and Washington DC to support the students in Tiananmen, often attended by thousands of overseas Chinese students and migrants. It collected the fax and telephone numbers of universities, companies and various other institutions in China, and distributed them to the branches worldwide. Coordinated faxing and calling campaigns were mounted. Everyday international reports were sent to China. This was intended to break China's official media control and inform its people of what was really happening in Beijing and other cities. In particular, protestors in China wanted to know how the rest of the world reacted to their activities. CAD strategists wrote an open letter giving detailed suggestions to the student leaders in Beijing, advising them to look beyond street protests, to undertake constructive work such as consolidating their organizations, publishing magazines, strengthening cooperation with the media, intellectuals and citizens, and maintaining dialogue channels with the authorities. This letter was eventually put up on the notice boards in the campuses in Beijing in the form of big-character posters. Central activists of CAD also held press conferences on Capitol Hill to brief the media and Congress on the escalating protests in China. Soon after the 4 June massacre, CAD successfully lobbied the United Nations (UN) Secretariat to turn a basement of its building into a mourning hall for the Tiananmen victims and fly all its flags in the front of the building at half-mast for half a day. A memorial service was held there on 17 June. ${ }^{26}$

\section{THRIVING OF THE MOVEMENT POST-TIANANMEN}

The military crackdown in June 1989 eventuated in a drastic expansion of the overseas democracy movement. CAD no longer dominated the scene. The crackdown caused a mass exodus of students and intellectuals from Beijing and the provinces. In particular, those active in Tiananmen Square had become glamorous political stars due to the intense international media coverage of their activities in China. At a meeting in Paris in September 1989, the newcomers to the OCDM announced the establishment of the Federation for a Democratic China (FDC). Meanwhile, the All-US IFCSS and its counterparts in other Western countries continued to lead campus-based political activism. Other less noticeable groups, consisting of many committees, foundations, societies, liaison groups and newspapers, also emerged in the Chinese diaspora. At a joint

26 Ding (2009), pp. 260-63, 266-7, 269. 
conference in Washington DC in January 1990, delegates from about ten organizations turned up. ${ }^{27}$

The two lead organizations, FDC and CAD, expanded their global ranks dramatically with active participation from Chinese students and migrants. FDC established branches in 25 countries, boasting more than 3000 members. ${ }^{28}$ CAD also rejuvenated itself and reached a similar number of members by the end of $1989 .{ }^{29}$ Though it is difficult to count exact organizational membership numbers since many hastily joined up in the heat of Tiananmen, Wang Min, a veteran dissident and first deputy president of CAD, later estimated that his organization and FDC together maintained 7000-8000 members by $1993 .^{30}$

Membership upsurge reflected a favourable broad operational environment. The Tiananmen killings agitated the overseas Chinese communities worldwide. For all the relevant elements - the Chinese students, Laoqiao and the emerging new migrants from China - resentment against Beijing became the norm. For example, when Wuer Kaxi and Wan Runnan (first vice president and secretary general of FDC, respectively) gave speeches on their worldwide tours, conference halls were always packed, with many attendees signing FDC's membership forms on the spot. Cash flooded into the hosts' donation boxes. Among the most zealous who joined the overseas democracy fight were people whose political and personal resonance with the leading exiles was strengthened by the Tiananmen crackdown. Depending on their ages and family background, some had suffered from persecution and even imprisonment in Mao's time due to their political activities, some had seen their parents persecuted, and some had had their political wake-up calls during the Cultural Revolution, when they witnessed rural China's backwardness and brutality as the so-called "sent-down youth" were banished to remote

\footnotetext{
27 Chen, Li and Lu Wei (1993-4).

28 Qi, Mo (2012), Wo de minyun lu: xin dao shui jin chu zuo kan yun qi shi [My Path in the Democracy Movement: Watching the Cloud at the End of the Water], Hong Kong: Yu Heng Press, p. 48. Qi was president of FDC, 1998-2003.

29 Zhou, Yicheng (2010), 'Survey of Chinese political movement in exile over the past 20 years', $B S$, October, p. 77.

30 Ziyou Zhongguo zhi Sheng (Voice of Free China) (2018), 'Democracy movement pioneer Wang Min talks about the overseas movement's history, current state and opportunities of the era', 4 January, available at https://www.youtube.com/watch? $\mathrm{v}=$ yPKJ0z6NsIk. Wang is now the president of the Chinese Democracy Party National United Headquarters (New York). According to Fei Liangyong, president of FDC 2003-12, his organization alone had more than 10000 members during the early 1990s (personal email: 1 November 2018).
} 
areas. ${ }^{31}$ The 1989 killings mobilized these people and others to take part in the OCDM in a way that, earlier, CS could not achieve on a similar scale.

Fertile ground for a democracy campaign was also provided by Western nations' universal condemnation of the Tiananmen Massacre, economic and diplomatic sanctions against Beijing, and sympathy for the exiles and overseas Chinese students at large. For example, in Australia, protest marches organized by Chinese student activists in various capital cities in the aftermath of the massacre were easily able to galvanize thousands of participants including large numbers of local residents from different walks of life. One Sydney-based campaign group was even offered an office by the New South Wales Labour Council. Students were moved by the mainstream support, especially when they saw Bob Hawke, the then prime minister, weeping as he spoke at a memorial service at Parliament House on 9 June. 32 At FDC's inaugural ceremony in Paris in September 1989, representatives from more than 60 international political parties, including a future French president (Nicolas Sarkozy), attended to express congratulations, and reporters from 150 media agencies came to cover the event. ${ }^{33}$ Indeed, France was the first country to provide settlement to the 1989 escapees through its Consulate General in Hong Kong. In the grand bicentennial parade of the French Revolution in Paris in July that year, some exiled students and intellectuals were on the platform, and some formed the first team walking past the platform. Many were carried away by the thought that the world saw them as the latter-day torch-bearers of the French Revolution, with its celebrated mottos on human rights. ${ }^{34}$

Of the Western nations' foreign policy measures to penalize China, none made the party-state more vulnerable and the exiles more encouraged than the US' decision to link its annual decision-making on China's Most Favoured Nation (MFN) trade status to its human rights record. Every year the exile dissidents effectively used Congressional debate to present their proposals to force changes in China as a condition of retaining its MFN status. They also benefited from the role of the then Assistant Secretary of State Winston Lord (1993-7), who emphasized

31 See, for example, profiles of a group of students in Australia who turned democracy activists in 1989, in Callaghan, Greg (2009), 'Remembering Tiananmen', The Weekend Australian Magazine, 16-17 June, pp. 18-22.

32 Ibid., pp. 20-21.

33 Qi (2012), p. 47.

34 Xu, Zhiyuan (2014b), 'Master Wan in Paris (1)', Jinrong Shibao (Financial Times), 31 July, available at http://www.ftchinese.com/story/001057512?full=y. 
human rights due to his personal engagement with the student activists at Beijing University during his ambassadorial time in China (1985-9). ${ }^{35}$

The Washington DC-based National Endowment for Democracy (NED), commonly seen both overseas and in Beijing as the main Western regular funding body for the OCDM, started its systematic support for the exiles in late 1989. In order to handle the emergency situation, NED assisted the dissidents in setting up a Foundation of Human Rights and Democracy in China (FHRDC) in September 1989 in order to channel funding to various organizations, though predominantly FDC, CAD and IFCSS. Reportedly, NED started with hundreds of thousands of US dollars, and disbursed $\$ 216000$ in 1991. Apart from funding hardcore dissident groups, NED also supported newly arriving intellectual exiles in their effort to conduct and publish policy-oriented research. One major example was the grant to the Centre for Modern China set up at Princeton University in 1990 by Chen Yizi, a former aide and senior policy adviser to the ousted Communist Party chief Zhao Ziyang. Seperately, NED seemed to have rediscovered $C S$, and unprecedently approved a grant of US\$45000 to the magazine in June 1992.36

It is commonly believed among dissident circles that as a whole, Taiwan was easily the largest financial sponsor for their movement up to the mid-1990s. Exact information is hard to collect due to many recipients receiving funding from more sources in Taiwan since Tiananmen. Pang Jia-jun, a former MIB colonel researching mainland dissidents abroad, has claimed that for about ten years until the mid-1990s, MIB channelled US\$5 million to the OCDM. ${ }^{37}$ This may be just part of the Taiwan funding, though MIB seemingly remained the main conduit of money supply. Since June 1989 other funders included pro-KMT media groups, the party's periphery associations such as the Grand Alliance for China's Reunification under the Three Principles of the People, and the ROC diplomatic representative offices overseas. ${ }^{38}$

Under those enabling circumstances, the cashed-up and high-spirited overseas dissidents and their organizations went out of their way to

35 Huang, Cun (1989), 'Liu Gang and democracy salon at Beijing University', CS, December, p. 57.

36 Yu, Dahai (2018), Wo de Zhongguo xin [My Chinese Heart], unpublished memoir of Yu Dahai, pp. 18, 24-6, 54-94. Yu was the president of CAD (1991-3) and remains publisher of BS. Yu, Dahai (2010), 'The NED I know', Wanwei Duzhe Wang (Creaders Net), 6 October, available at http://blog.creaders.net/u/4775/201812/336837.html.

37 Pang, Jia-jun (2010), Qingbao zhaji: Taiwan Junqingju gaoguan huiyilu [Intelligence Diary: Memoir of a Senior Officer of Taiwan's MIB], Hong Kong: Cultural and Art Press, p. 241.

38 Qi (2012), pp. 74-8. 
campaign for their cause. This included active Congressional lobbying on China's MFN status in the US, giving evidence at the legislative public hearings in other Western states on China's human rights abuses, and making presentations at the UN Commission on Human Rights in Geneva, which had become a key forum where member states frequently debated China's political repression. In addition, mass protest rallies were frequently staged in front of Chinese diplomatic missions worldwide and the UN headquarters. The main designated occasions were the anniversaries of the 4 June Beijing massacre, the PRC's National Day (1 October), visits by Chinese leaders, and Beijing's release of its official white paper Human Rights in China (1991). In those years the Chinese embassies and consulates were often busy fending off large crowds of protesting compatriots.

One action with more tangible foreign policy implications was $C S^{\prime}$ ' role as the central platform to constantly publish and update the names of those killed, wounded, arrested and jailed as a result of leading or participating in Tiananmen protests. These names were supplied by a variety of sources inside China, including the families of the victims. From mid-1989 to late 1993, CS published more than 1000 names, some with court verdicts and appeals. Dissidents gave the $C S$ lists of names to leading Western governments, including the few officials who visited Beijing at the time, requesting them to present the cases to the Chinese government. Such information was crucial for Western states to put pressure on Beijing in their bilateral human rights dialogue sessions. ${ }^{39}$

\section{ADVANCING AMID DISUNITY WRIT LARGE}

A major consensus emerging from the exile community was to see CAD and FDC, the two leading groups spearheading the movement, merging into one giant organization. The former was the pioneer of the OCDM with established operational capacities, and the latter enjoyed the legitimacy and glamour of Tiananmen superstars. These new students and intellectuals might have initially decided not to join CAD since they had heard of the infighting in Flushing and Wang Bingzhang's dismissal. However, it was only natural that organizations sharing exactly the same goal of China's democratization should merge to mount a final assault on what looked like a crumbling regime in Beijing at the time.

The long-awaited historic conference to complete the merger and elect leadership of the new organization was held in Washington DC in

\footnotetext{
39 Chen, Li and Lu Wei (1993-4).
} 
January 1993. With Taipei chipping in hundreds of thousands of US dollars for the event, expectations ran extremely high. ${ }^{40}$ CAD and FDC each sent 100 delegates selected from both headquarters and branches. Agreement was reached to name the proposed new organization the Federation of Democratic Alliance (FDA). What eventuated, however, was nothing short of a fiasco. Instead of democratically selecting delegates, some leadership contenders from both organizations rigged the process to fill the seats with their own favoured people, in order to maximize the votes in the ultimate elections. This discovery caused their competitors to withdraw from the race and leave the conference in order to protect procedural integrity. Despite such protest and an increasingly chaotic gathering, Xu Bangtai, hitherto a second-tier leader of CAD, collaborated with his supporters and pressed ahead with the remaining attendees. He won the controversial elections with little competition, and declared himself the founding president of FDA. However, leaders of FDC and CAD refused to recognize the legitimacy of Xu's position, and carried on with their existing organizations with the support of most of their branches, effectively putting FDA's legitimacy as an organization in doubt. This did not prevent $\mathrm{Xu}$ and his supporters from taking action to challenge the legality of the continued existence of CAD and FDC. Throughout 1993-4, leaders of CAD and FDA took each other to court repeatedly without achieving any result other than wasting valuable financial resources. However, $\mathrm{Xu}$ did win in a separate legal battle to wrestle control of $C S$ from CAD. His argument was that since it was part of $\mathrm{CAD}$, which should not have continued to function in the first place, $C S$ should now be handed over to FDA. Both sides quickly became unable to cope with the legal costs, and the distraction jeopardized the routine publishing of CS. Consequently, an out-of-court settlement was reached. CAD ceded control of the magazine to FDA, and started to publish a new magazine, Beijing Spring (BS), from June 1993.41 Thus, $C S$, a dissident magazine that had made such a distinct impact both in China and abroad for just over ten years, was taken over by an ill-born organization with a shaky start under an arguably illegitimate leader. The FDA was to disintegrate in a few years due to mismanagement and alleged corruption amongst the organization's leadership. ${ }^{42}$

While the spectacular failure of the merger campaign dampened the momentum of the OCDM and caused widespread repugnance to some

40 Ziyou Zhongguo zhi Sheng (Voice of Free China) (2018).

41 Chen, Li and Lu Wei (1993-4).

$42 \mathrm{Xu}$ Bangtai, who had a doctorate in political science, disappeared around the late 1990s amid allegations of embezzling Taiwanese funds. 
leading activists, it was not to become a Waterloo of the movement. New excitement came quickly. Reflecting its vulnerability in front of Western states' human rights diplomacy in the post-Soviet world, China compromised and started to banish some major dissidents to the West as a result of diplomatic bargaining. Usually in the name of medical parole, some of these dissidents were literally requested to pack up in jail and leave straight from their cells for the US. Thus Wang Juntao, Wang Xizhe, Wei Jingsheng and Wang Dan arrived on the exile scene, in 1994, 1996, 1997 and 1998, respectively. Fresh hope surged that these historic heroes could help integrate the fragmenting democracy movement.

Wei Jingsheng was widely touted in the world as the "father" of the Chinese democracy movement, initially due to a big-character poster he wrote in the Democracy Wall movement calling for "Fifth Modernization", which landed him in jail for a 15-year sentence. His treatise denounced Deng Xiaoping as an emerging post-Mao dictator, and argued that the new leader's drive for industrial, agricultural, scientific and defence modernizations should proceed with an additional political democratization or "Fifth Modernization". ${ }^{33}$ Wei became a household name among Chinese students, intellectuals and workers born during the 1950s and 1960s. No talk of the Democracy Wall, or the subject of the Chinese democratization cause in general, can be complete without mentioning him. His bravery and simple theory inspired those Beijing students who took to Tiananmen Square in 1989, though he was still incarcerated at the time. He was an icon and a flag of their grand cause. Wei was released briefly in 1993 but was imprisoned again in 1994 for a new sentence associated with his continual dissident activities. Meanwhile, he was showered with international awards as a human rights and democracy crusader. They include the International Activist Award by the Gleitsman Foundation (1993), the Olof Palme Memorial Prize (1994), the Robert F. Kennedy Memorial Human Rights Award (1996), the European Parliament's Sakharov Prize for Freedom of Thought (1996), and the National Endowment for Democracy Award (1997). Since 1993, Wei has been also nominated seven times for the Nobel Peace Prize. ${ }^{44}$

When he was forced to leave jail for the Beijing Capital International Airport in November 1997, Wei had spent a total of 18 years in different prisons across multiple provinces. Wei's arrival in the US caused an

43 Wei, Jingsheng (1998a), 'The fifth modernization: democracy', in The Courage to Stand Alone: Letters from Prison and Other Writings, London: Penguin, pp. 199-212.

44 This information is sourced from the website of Wei Jingsheng Foundation, available at http://www.weijingsheng.org/wei/en.html. 
international sensation. As this author personally witnessed, his appearance at numerous events attracted huge audiences, Chinese and otherwise. On one occasion in Melbourne, Australia, some elderly trade unionists showed him the placards they used while demonstrating for his release in the early 1980s (Wei was a technician at Beijing Zoo in the 1970s). The then US President Bill Clinton met him at the White House and claimed that he had read Wei's book. This one-on-one chat was the highest honour ever bestowed by the US establishment on a Chinese dissident. ${ }^{45}$ Basking in the media whirlwind, the legend travelled all around the world with invitations from fellow luminaries including Nelson Mandela and Vaclav Havel. Such scenes of former dissidents and prison inmates who had turned into leaders of their states conjured up imagination among Wei's worshippers that he might be embarking on the same path - and Wei would not disagree with them.

Wang Juntao, one of the leading intellectuals behind the Tiananmen Square demonstrations, was accused by the government of being a "black hand" and instigating impressionable youth. He was sentenced to 14 years imprisonment. Significantly, Wang started to organize dissident activities in 1976, when he was just 17. In April that year, he took a group of high school classmates to Tiananmen Square to protest the political repression of the Mao era, and was imprisoned for half a year. He went on to participate in the Democracy Wall movement. Throughout most of the 1980s he was well-known in Beijing as the driver of some liberal think tanks and newspapers. Remarkably young for this background, Wang was warmly received on Capitol Hill in May 1994, at a ceremony to welcome him organized by the Majority Leaders of both the Senate and House, shortly after his arrival in the US. Just like Wei, Wang was also picked up in jail and sent abroad immediately in the name of medical parole.

Another historic activist who received the same treatment four years later was Wang Dan. During the Tiananmen Square demonstrations, this 20-year-old history student of Beijing University was a leader in the BSAF and one of the organizers of a hunger strike which captured the imagination of the international media. The fact he was placed by the Chinese government as number one on the list of the 21 most wanted student leaders of the protests testified to his significance.

Between the arrivals of the above two Wangs, there was another important Wang Xizhe, who fled to the US in late 1996. He first achieved

45 Chen, S. and W. Huang (1997), 'Wei Jingsheng and China's next "Long March", The Christian Science Monitor, 23 December, available at https://www.csmonitor.com/ 1997/1223/122397.opin.opin.1.html. 
fame as early as 1974, when, as a factory worker, he used big-character posters in Guangzhou to criticize political and economic privileges of the cadre class and call for democracy and rule of law. He went on to organize dissident activities in Guangzhou to support the Democracy Wall movement in Beijing. Consequently, he spent 12 years in prison (from 1981 to 1993). Like Wei Jingsheng, born in 1950, the 1948-born Wang Xizhe was also regarded as one of the elder leaders of the democracy movement.

Impacts on the overseas democracy movement of these fresh arrivals were mixed. Wang Juntao and Wang Dan chose to pursue academic studies at Columbia University and Harvard University, respectively. The exile community was particularly fixated on Wei Jingsheng to lead the movement. He lost no time in trying to assume that role. In November 1998, he formed the Overseas Chinese Democracy Coalition (OCDC) as an umbrella forum to achieve unity within the movement. Meanwhile, the number one Democracy Wall veteran enjoyed travelling to Geneva to unnerve the Chinese delegates at the UN Commission on Human Rights, by attempting to mobilize votes to pass resolutions aimed at investigating human rights conditions in China.

However, the much hoped-for grand unity of the exile movement failed to eventuate. Wei faced fierce opposition from no other than Wang Xizhe, the other elder activist. If the overall exile community at the time could be defined as a rivalry of "multiple mountains", a term often used by activists themselves to refer to the fragmentation of the movement, then Wei and Wang seemed to form the two biggest mountains. As soon as OCDC was established, Wang and his supporters formed a rival Overseas Democracy Movement Organizations Roundtable Conference. The two elders exacerbated the intra-movement tension. Wang's position was that Wei should not be allowed to play a hegemonic role in the dissident circles and should instead openly declare a rejection of the title "father" of the Chinese democracy movement. He frequently ridiculed Wei's nomination for the Nobel Peace Prize. The ultimate disgrace came in January 1999, when Wang and his supporters invited themselves to a public hearing session on Chinese human rights hosted by the Committee on International Relations of the House of Representatives, which only invited Wei and his close followers. Wang interrupted the session and challenged some Congressmen as to why he had not been invited. Supporters of the two epic democracy crusaders shouted at each other and clashed physically, pushing and shoving each other, even knocking 
over chairs. Security guards intervened to stop the escalating fight. ${ }^{46}$ Any hope of an all-movement integration was symbolically dashed, and the disunity of the OCDM was on public display right in the US Congress.

Study of transnational social movements posits that the development of movements and effectiveness of campaigns are not only influenced by activists' tactics in reaction to political opportunity structures, but also significantly conditioned by "actor characteristics". Activists with effective transcultural communication and campaign skills, and dense exchanges and close solidarity between the various organizations, are among the enabling elements for the movements. ${ }^{47}$ The following section tries to cast light on the reasons and consequences of the leading dissidents' chronic infighting, a phenomenon which has plagued exile politics to this very day, though with declining magnitude over the years.

\section{INFIGHTING: REASONS AND CONSEQUENCES}

As a crippling factor, infighting first emerged in CAD with the expulsion of the founding president Wang Bingzhang from the organization just before the Tiananmen Square demonstrations. The scale became more expansive with the merger saga in 1993. New fuel was added to the fire with the involvement of famous democracy elders towards the end of the 1990s. Hostilities flared up within and between dissident organizations, and among activists of the same generation and across generations. The examples depicted above were merely the most noticeable ones.

The tension had little to do with disputes over fundamental political ideals. It is true that some leading activists used to be renowned beneficiaries of the party-state's reform policy before exile. For example, Wan Runnan, the first Secretary General of FDC before being elected as its president (September 1990-May 1996), was the founding chairman of the Stone Group, the Chinese computer software giant. As mentioned earlier, Chen Yizhi, also an FDC leader serving with Wan, was a former aide and senior policy adviser to the ousted Communist Party chief Zhao Ziyang. However, they were among the elite elements that enthusiastically supported the Tiananmen demonstrations and had to flee China for

46 Tie, Mian (1999), 'A true report of democracy activists' sudden and fierce dispute in the US Congressional hearings', Pingguo Ribao (Apple Daily), 10 January, available at http://cdjp.org/dinfo/cdjp/Intro/congress011099; Fang, Bay (1999), 'The dissension among Chinese dissidents', U.S. News \& World Report, 126 (10), p. 42.

47 Keck, Margaret E. and Kathryn Sikkink (1998), 'Transnational advocacy networks in international politics: introduction', in Activists beyond Borders: Advocacy Networks in International Politics, London: Cornell University Press, pp. 28-9. 
that reason. They turned themselves from in-system reformists into democrats, hence their high profile in exile activism. ${ }^{48}$

In the overseas movement there were certainly different opinions on specific issues or campaign tactics, clashing egos of activists and their different self-interests. Allegations of corruption were frequently heard at a time when formal funding and cash donations were flooding into the coffers of some organizations. The leaders, particularly the activists leading a difficult fresh life in exile, were in a strong position to control and personally benefit from the money. However, these problems, and even the problem of factionalism, are common in political life. What made these problems escalate to severely undermine the potential of the movement and cause long-lasting personal animosities among many activists was a convergence of the following factors.

The influence of Maoist communist political culture was palpable. Many of the infighting events stirred up the memory of Mao-style political struggles and persecution, defined by a so-called "materialist dialectical" worldview. The great helmsman and his lieutenants often labelled critics of the regime, both inside the CCP or outside, as "rightists", "counter-revolutionaries", or "spies of the KMT", to be eradicated, not persuaded. An Qi, an exile author who was the first perceptive analyst of the OCDM's debilitating internal wrangling, claimed that many dissidents frequently acted like the Red Guards, Mao's stormtroopers who rampaged the establishment during the Cultural Revolution. Influenced by such an unhealthy psyche, dissidents were unwilling or unable to follow the democratic procedures which they had nominally agreed, so that losers in leadership contention often disrespected the results of elections or waited for procedural opportunities to seek personal revenge. An Qi further noted that some dissident leaders tended to use radical language and extreme expressions in communicating with comrades, and seemed to adopt a life-or-death approach when dealing with disputes. As a winning tactic, dissidents were also inclined to dig up personal dirt in order to destroy opponents' reputations. ${ }^{49}$

An Qi's early view is echoed by a more recent study. Rowena He, a Harvard researcher of Tiananmen argued that the splits, infighting, and inter-personal bitterness within the community of exiled dissidents arose mainly from their domestic political socialization experiences in China that focused on struggles against nature and the people, rather than

48 For a change of Chen, see Chen, Yizhi (2013), Chen Yizhi huiyilu [Chen Yizhi Memoir], Hong Kong: New Century Press.

49 Ya, Yi (2005c), 'Free soul and independent personality - interview with freelancer An Qi', in Liuwangzhe fantan lu [Interviews with Exiles], p. 390. 
conflict resolution and leadership..$^{50}$ Significantly, Wang Dan admitted as much. He attributed the infighting mainly to the beliefs formed and attitudes adopted by the activists in their early political education. Wang candidly admitted that while they had embarked on a pro-democracy path, many exile activists including himself had hardly shaken off all the legacies of the communist political culture which heavily influenced their formative years. Thus, they saw the political world in a black-or-white fashion, treating fellow travellers holding different opinions as enemies, and unable to use defined procedures and civil dialogue to settle conflicts. Hence different opinions often led to attacks and splits. ${ }^{51}$ It must be stressed that the only experiment of democratic governance Wang's generation had undertaken before exile was the establishment and operation of BSAF and its equivalents in the provinces in 1989. That exercise was far too short to cultivate sustainable democratic habits.

For the most famous exiles, those behavioural patterns of the Red Guards style might also have been reinforced by the debilitating personal ordeals they suffered before leaving China, as a result of arrest, torture and imprisonment. Rowena He claimed that she "observed signs and behaviour of post-traumatic stress disorder among almost every single exiled dissident whom I have encountered over the years, in both their personal and public lives". ${ }^{52}$ It could be commonly observed that some democracy veterans had their communication capacity and knowledge development weakened by the long years they had spent in jail. While living a life shut off from the world, they sustained their courage by imagining heroic struggles and their own historic roles. On release from detention and moving to the exile scene, they felt carried away by the realization that they had in fact become famous worldwide while still in jail, thanks to the persistent international media and diplomatic attention. Under such circumstances, it was hard for them to be modest, become cooperative, and more importantly, to learn new ideas and not to live in old glory.

Infighting became more likely as a result of the leading dissident organizations (particularly CAD and FDC) uncritically establishing a Western-style division of three governing powers in their decisionmaking processes. A basic belief of faith was that the practice of checks and balances, and other democratic trappings such as term limitation for the top leadership position, were indispensable if dissidents wanted to

$50 \quad$ He, Rowena (2014a), 'Citizenship in exile', in Tiananmen Exiles, p. 175.

51 Wang, Dan (2012b), Wang Dan huiyilu: cong liusi dao liuwang [Wang Dan Memoir: From 4 June to Exile], Taipei: Times Press, p. 348.

52 He (2014a), p. 175. 
demonstrate to fellow Chinese people how real democracy worked. The exile organizations' obsession with experimenting with the system of a liberal democratic state actually provided a convenient framework to facilitate the aforementioned feuds. Usually, when a candidate lost an election for the top executive post, the most important of the three positions, he would try for election to one of the other two leadership positions. Once successful, he would revengefully sabotage the work of the winner of the original elections in the name of checks and balances. This author personally witnessed formal elections at the Fourth World Congress of CAD in Los Angeles in late June 1989. Candidates for presidency, chairmanship of Alliance Commission (supposedly the legislative branch) and chairmanship of Investigation Commission (the judiciary) took part in what looked like an impressive democratic electoral process, with well-prepared debates and meticulously monitored vote counting. However, Xu Bangtai, the loser of the election for presidency, was to prove uncooperative with the winner (Hu Ping). In a few years, the power struggle finally became uncontrollable. At the CAD/FDC merger conference in 1993, the two men were among the candidates for presidency of the new organization. As alluded to earlier, $\mathrm{Xu}$ and his mob defied democratic procedures and forced $\mathrm{Hu}$ and others to withdraw from the race, before taking the entire CAD leadership to court and seizing its magazine, CS. It would take years before more and more activists learned the lesson of practising checks and balances, which was cumbersome for a group in exile under the best circumstances, and started to give more consideration to the idea of operating leaner, meaner, and more professional non-governmental organization (NGO)-type structures.

Infighting was also exacerbated by an overly optimistic assumption that the Chinese party-state was soon to fall - thus exiles could expect to return to participate in the regime change and even become leaders of the new regime, with or without joining the reformers in the CCP. While famous dissidents felt like this, other lesser ones believed that they might become influential power holders in the provinces and cities. The key for all was to scramble for top leadership positions in the larger dissident organizations to better their future chance back in China. The power struggle thus intensified, yet all came to naught.

In the aftermath of the Tiananmen Massacre, Liu Binyan, a wellrespected reporter and one of the senior spiritual mentors of the exile movement, declared that the discredited regime in Beijing was certain to 
fall in two years. ${ }^{53}$ Wan Runnan was slightly more conservative. In an article published in Wall Street Daily in August 1989, he predicted that the regime would collapse within six years, and that exiles like himself would go to Beijing to contest free elections to become new masters of the country. His sentiment was subsequently further beefed up by the regime change in Eastern European party-states and disintegration of the Soviet Union. ${ }^{54}$ As if to echo Wan's projection, Yan Jiaqi, director of the Institute of Political Science Research at the prestigious Chinese Academy of Social Sciences (Beijing) before exile, and the founding president of FDC (September 1989-September 1990), even made up a detailed six-year plan for regime takeover. It envisaged a process like this: within two years from 1989, reformers in the regime would positively redress the nature of the Tiananmen event, and all exiles would go home. In the following two years, new political forces would eradicate the influence of Mao Zedong Thought and work out a new democratic constitution. During the final two years in Yan's vision, elections would be held under a new democratic system. ${ }^{55}$ So excited were the exiles by the prospect of regime change at home that they formed delegations to tour the changing political situations in Eastern Europe from 1990, in order to learn how a nation could transform from a one-party dictatorship to democratic governance. ${ }^{56}$ Indeed, the whole world seemed to share the Chinese exiles' excitement with the collapse of the Soviet bloc and their doubt over the sustainability of the Beijing regime.

Though the post-Tiananmen regime in China appeared not to be collapsing as wished, dissidents pinned their hopes on what they assumed was to become an unmanageable situation after the death of the octogenarian paramount leader Deng Xiaoping, who was responsible for the 1989 massacre. Deng died in February 1997, at the age of 93 - and yet the regime was not shaken. Instead, under Deng's hand-picked leadership of President Jiang Zemin, the national economy embraced years of prosperous development. Since then, dissidents have generally stopped imagining a scenario of exiles taking over the regime. Instead, admission of over-optimism was forthcoming from some of the original wishful thinkers. During an interview in 1998, Liu Binyan admitted that in 1989 he failed to expect two scenarios. First, while the regime changes in the

53 Ya, Yi (2005d), 'People are always where strength lies - interview with writer Liu Binyan', in Liuwangzhe fantan lu [Interviews with Exiles], p. 290.

$54 \mathrm{Xu}(2014 \mathrm{~b})$.

55 Qi (2012), pp. 216-17.

56 For CAD's elaborate vision for regime takeover in 1990, see Chen, $\mathrm{Li}$ and Lu Wei (1993-4); and Lu, Bian (1990), 'Right-turn in Eastern Europe and its inspirations for us', May, $C S$, p. 3. 
Soviet Union and Eastern Europe were initially a positive influence over China's democratization, the resultant social turmoil and economic hardship in post-Soviet Russia and other states scared the Chinese people out of enthusiasm for democracy. Second, he argued that economic reform in China was supercharged by Deng's attempt to save the post-Tiananmen regime, and a tidal wave of new business activities improved the people's lot. ${ }^{57}$ The bursting of the regime takeover dream removed one incentive for infighting but it also caused some disappointed activists and organizational members to lose their political zeal.

Not all of the prominent dissidents became involved in the debilitating power struggle. Many in fact consistently expressed repugnance towards it. Also, those who were party to infighting were responsible for its scale and bitterness to very different degrees. Regardless, infighting caused severe harm to the reputation of the OCDM as a whole. It made some activists unwilling to continue, and forced others to leave the movement. Crucially, incessant intra-movement feuds went a long way to confuse and disappoint Western and Taiwanese supporters and funders. While information of decreasing individual donations and informal ad hoc funding was hard to collect, decline of regular money supplies from established entities were observable and keenly felt by the recipients.

One long-time leader of CAD admitted that the 1993 merger fiasco and the subsequent legal battle between FDA and CAD particularly saddened Taiwanese funders and shattered their confidence in those money-wasting dissidents. After 1993, Taipei decided to only fund CAD's magazine, not the organization. Thus the standard supply of US\$60000 per month was halved. ${ }^{58}$ In his memoirs, a senior MIB officer dealing with the OCDM took pains to express his frustration and gave scathing criticism of the rampant internal bickering within the exile community. ${ }^{59}$ NED was similarly flabbergasted by the disunity in the exile scene, particularly the merger fiasco which occurred under the funding body's nose. FHRDC was closed down in 1993. Meanwhile, NED's first grant of US\$45000 to CAD, offered in 1992, was to become the only one ever given to the latter. The CAD leadership tried to reason with NED that at least their new magazine $B S$, which started to publish from mid-1993 and received support from Taiwan, should be funded by NED. Unfortunately, NED officers made it unequivocally clear that the funding body had developed an unwritten rule that no money should be given to any of the major parties involved in the 1993 fight, irrespective of who was the main

57 Ya, Yi (2005d), p. 290.

58 Interview with Xue Wei; Yu (2018), pp. 27-39.

59 Pang (2010), pp. 235-44, 279-99. 
culprit. NED even rejected CAD's application in 1995 for a small grant to cover postage to send $B S$ to China. ${ }^{60}$

\section{CONCLUSION}

The genesis, growth and expansion of the exile campaigns for democracy and human rights can be attributed to the two most important political revolts in the era of PRC's economic reform. While the leading activists of the Democracy Wall movement were all locked away, their pioneering and brave activities inspired the broader community of students, intellectuals and professionals. Some of these elements, such as Wang Bingzhang, reignited the spark of struggle once moving to the Western world. The Tiananmen Square demonstrations, particularly the 4 June military crackdown, expanded the ranks of exile political campaigns. Students and intellectuals who were the main drivers for political liberalization in China during the 1980s fled the country in large numbers, from Beijing and various provinces. Mass participation in the movement also came from the Chinese diaspora community. Momentum was further fuelled by the sympathy and support from leading Western nations and Taiwan, though for different reasons.

In what they liked to call "the free world", the exiles capitalized on the sort of political freedom and human rights that they had all along imagined and yearned for in China, to campaign for the realization of such democratic traits in the homeland. Excitement and a sense of historic mission were evident, since the struggle and various campaigns were all first-time experiences for the activists. They became part of the mounting international pressure on the Chinese party-state. However, despite their shared goals, the unprecedented enjoyment of freedom of association also exposed the dissidents' own behavioural flaws which were cultivated and cultured in the very system which they sought to change and overthrow. The upsurge of exile activism was obstructed by recurring infighting, which caused a split in the movement, lowered morale, and made supporters and funders disillusioned. As an old Chinese saying goes, one mountain cannot accommodate two tigers. When democracy stars descended in the major Western capital cities, more tigers started to roam the forests. The movement was unable to

$60 \mathrm{Yu}$ (2010). NED started to fund $B S$, not the organization of CAD, in 2001 in order to rescue the magazine from a dire situation caused by Taipei's drastic funding cut, as discussed in Chapter 2. 
mobilize its full potential even when the party-state was struggling and external support for the exiles was strongest.

More seriously, while the infighting was raging, the ground under the exiles' feet was beginning to shake, first quietly, then loudly. More fundamental than disappointment with infighting in deciding to reconsider their cooperation with the OCDM, key strategic supporters' relations with the PRC started to change from the mid-1990s. By the late 1990s, it was more than clear that the rise of the Chinese economy, as a market and trader, was reshaping Western and Chinese diasporic relations with the country, diminishing support for the OCDM or the cause of Chinese democratization at large. Meanwhile, Taiwan's accelerating de-Sinification campaign distanced itself from Chinese politics. One by one, these strategic changes worsened the exiles' operational environment (as discussed in the next chapter), and sent the internally split movement down the hill, a trend most noticeable from the beginning of the 2000s. 